\title{
A Study on Polyculture of Oyster (Crassostrea gigas), Sea Squirt (Halocynthia roretzi) and Sea Cucumber (Apostichopus japonicus) under a Hanging Culture System
}

\author{
Young Dae Kim ${ }^{1}$, Yun Kyung Shin ${ }^{1}$, Mi Seon Park ${ }^{1}$, Hee Jung Lee ${ }^{1}$, Jun Wook Hur ${ }^{2}$, \\ Myoung Ae Park ${ }^{1}$, Yong Hyun Do ${ }^{1}$, Khawaja Muhammad Imran Bashir ${ }^{3,4}$, Jae-Suk \\ Choi $^{4,5, *}$, (1)
}

${ }^{1}$ South East Sea Fisheries Research Institute, National Institute of Fisheries Sciences, Tongyoung-si, Gyeongsangnamdo, 53085, Republic of Korea.

${ }^{2}$ Bio-Monitoring Center, B-dong, 325, Sejong Business Center, Garam-ro, Sejong-si, 30121, Republic of Korea.

${ }^{3}$ German Engineering R\&D Center for Life Science Technologies in Medicine and Environment, 31, Gwahaksandan 1ro, 60 beon-gil, Gangseo-gu, Busan, 46742, Republic of Korea.

${ }^{4}$ Seafood Research Center, IACF, Silla University, 606, Advanced Seafood Processing Complex, Wonyang-ro, Amnamdong, Seo-gu, Busan, 49277, Republic of Korea.

${ }^{5}$ Major in Food Biotechnology, Division of Bioindustry, College of Medical and Life Sciences, Silla University, Busan, 46958, Republic of Korea.

\section{Article History}

Received 09 November 2017

Accepted 07 March 2018

First Online 25 October 2019

\section{Corresponding Author}

Tel.: +82512787789

E-mail: jsc1008@silla.ac.kr

\section{Keywords}

Aquaculture

Hanging culture system

Polyculture

Sea cucumber

\begin{abstract}
This study aimed to develop a novel polyculture technology for sea cucumber using seabed under hanging culture farms of oyster and sea squirt. The survival, growth and sheltering rates of sea cucumber seedlings were determined. The habitation rate of sea cucumber was $20 \%$ with $20.8-31.0$ animals per shelter. The density was calculated to be 3 animals per $\mathrm{m}^{2}\left(\mathrm{~m}^{2} \times 3 \times 900=2,700\right.$ animals $)$, which shows that approximate $2,000 \mathrm{~kg}$ of sea cucumbers could be produced from 1 ha $\left(10,000 \mathrm{~m}^{2} \times 200 \mathrm{~g}\right.$; when one individual grows every $\mathrm{m}^{2}$ ). Even though seabed under the hanging culture farms is muddy and not suitable for rearing sea cucumbers, the results of this study showed that polyculture of sea cucumber is possible using the oyster and sea squirt hanging culture farms. Therefore, the method of utilizing the bottom surface in a hairstyling farm is proposed as a new aquaculture model for sea cucumber farming. The results of this study could contribute to improve the culturing environment of sea cucumbers and could help to increase production and capital generation from the aquaculture farms.
\end{abstract}

\section{Introduction}

Sea cucumbers, an abundant member of marine benthic communities, have important functions within the marine ecosystem. By reducing the organic load and bioturbation of surface sediments, sea cucumbers could act as bioremediators for coastal mariculture (Solan et al. 2004; Purcell et al. 2004, 2012). By feeding on organic detritus mixed with sand and silt, and by excreting the inorganic nitrogen and phosphorus, sea cucumbers enhance the productivity of benthic biota through nutrient recycling and sediment cleaning (MacTavish et al. 2012; Yuan et al. 2015; Purcell et al. 2016), which are important factors for ecosystems in oligotrophic waters such as coral reefs. Sea cucumbers also enhance the seawater alkalinity by feeding and releasing of ammonia which contributes to local buffering of ocean acidification (Schneider et al. 2011, 2013). Organic matter present in the sea is usually sufficient source of food for sea cucumbers, however, additional organic detritus and food could increase the growth rate and rearing density, especially in spring and autumn (Change et al. 2004). Thus, culturing sea cucumber together with different marine species with complementary feeding 
habits such as oyster and sea squirt could be beneficial for sea cucumber growth in polyculture. This would have both environmental and economic benefits, and the polyculture methods could contribute to the sustainable development of aquaculture (Yu et al. 2012).

Approximately, 1500 species of sea cucumber are known worldwide, including the green, red and black sea cucumber species found in the Korean waters (Bordbar, Anwar \& Saari, 2011). Sea cucumbers are currently farmed on coastal seabed consisting of sand, pebbles and algae. It is known that an optimal habitat for sea cucumbers has velocities ranging from $0.2 \mathrm{~m} / \mathrm{s}$ to $0.4 \mathrm{~m} / \mathrm{s}$ and water temperatures ranging from $10^{\circ} \mathrm{C}$ to $14^{\circ} \mathrm{C}$. They feed on sediment organic matter (Yingst, 1982; Moriarty, 1982; Ahlgren, 1998). The waters of the Gyeongsangnam-do province on the southeast coast of the Republic of Korea are concentrated with hanging culture farms, particularly for 5 main aquaculture species such as oyster, scallop, sea squirt, mussel and stalked sea squirt of which combined production of $335,435 \mathrm{MT}$ accounts for $76.7 \%$ of their national total production (437,586 MT; MOF, 2017). In particular, the aquaculture farms in the Gyeongsangnam-do province contribute $98.5 \%$ of the Korean national total production of Pacific oyster, mussel and sea squirt. However, the continued farming practice has lowered efficiency and productivity of these farms (NIFS, 2009a). As hanging cultures only utilize surface and middle layers of the water, there is a need to develop a farming method to utilize seabed.

Seabed under hanging culture farms is mostly muddy without rocks and pebbles, thus it is not considered a suitable place to rear sea cucumbers (Kim, Son, Cho \& Jin, 2016). Various studies have been conducted on polyculture of sea cucumber such as polyculture of abalone and sea cucumber (Nam, Lee, Moon, Kim \& Hwang, 2011); polyculture of scallop and sea cucumber in cages rearing scallops (Yang, Hamel \& Mercier, 2015); sea cucumber-based polyculture using hanging strings or rafts (cage culture) to utilize high filtration capacity of shellfish (Paltzat, Pearce, Barnes \& Mckinley, 2008); capacity of sea cucumber to consume scallop feces (Yuan et al. 2008); the impact of polyculture on stability of farming facility (Mu \& Song, 2005); study on the problem of water temperature (Xing, Liu, Yang, Zhang \& Zhou 2012); utilizing shelters for indoor farming; sea cucumber physiology (Kim, Son, Cho \& Jin, 2016) and distribution (Kim et al. 2017b); as well as shellfish filtration in hanging culture in the coastal ecosystem (Jaramillo, Bertrain \& Bravo, 1992; Hatcher, Grant \& Schofield, 1994). However, the feasibility of sea cucumber polyculture on seabed under oyster and sea squirt hanging culture farms installed on the surface and middle layers of water has not been yet explored.

To overcome challenges resulting from intensive hanging cultures such as low productivity and mass mortalities and to establish an eco-friendly and sustainable aquaculture system, it is necessary to develop an alternative technique for sea cucumber polyculture which could help to achieve multidimensional utilization of water and to improve marine environment. The present study aimed to develop a novel sea cucumber-based polyculture technique by utilizing unused seabed under hanging culture farms of oyster and sea squirt, which would ultimately contribute to generate higher capital from aquaculture farms.

\section{Material and Methods}

\section{Survey Sites}

Survey was carried out at a sea squirt hanging culture farm located at Yeongun-ri, Sanyang-eup, Tongyeong-si, Gyeongsangnam-do, Rep. of Korea and an oyster hanging culture farm located at Osong-ri, Dongbu-myeon, Geoje-si, Gyeongsangnam-do as shown in Figure 1.

\section{Data of Sea Cucumber Shelters}

For juvenile sea cucumbers, double-sided grooved shelters with a size of $590(\mathrm{~L}) \times 360(\mathrm{~W}) \times 120(\mathrm{H}) \mathrm{mm}$ were installed in the hanging culture farms of sea squirt and oyster and for late-juveniles, shelters in a size of 590 $(\mathrm{L}) \times 360(\mathrm{~W}) \times 180(\mathrm{H}) \mathrm{mm}$ with grooves on one side and passages on the other side were used. A detailed design of sea cucumber shelters installed in the sea squirt farm in Tongyeong-si and the oyster farm in Geoje-do is shown in Figure 2. The release of sea cucumbers in the installed shelters is shown in Figure 3 and the growth of sea cucumbers in actual installed shelters is shown in Figure 4. As shown in Figure 2, a total area of $30 \times 30 \mathrm{~m}$ $\left(900 \mathrm{~m}^{2}\right)$ was divided into 4 sub-areas: type $A$ shelter (top left and bottom right) area consisted a single subunit total of 36 shelters including 12 shelters for juveniles and 24 shelters for late-juvenile sea cucumbers; type B shelter (top right) area consisted of 4 subunits of 3 juvenile shelters and 9 late-juvenile shelters; type $C$ shelter (bottom left) area consisted of 2 sets of 3 subunits of 1 juvenile shelter and 2 late-juvenile shelters with the addition of type $B$ shelter; and type $D$ shelter area consisted a set of type A shelters. Each subarea sized $5 \times 5 \mathrm{~m}\left(25 \mathrm{~m}^{2}\right)$ and an interval between subareas was maintained at $16 \mathrm{~m}$.

\section{Installing Shelters and Juvenile Releasing}

Shelters were placed under hanging culture farms of sea squirt and oyster on April 30, 2016 and juveniles were released on the same day. A total of 20,000 hatchery-reared juveniles (mean weight: $3.7 \pm 2.9 \mathrm{~g}$ ) were reared and 10,000 were released into each of the sea squirt farm and the oyster farm. Five thousand wild late-juvenile sea cucumbers were also released into each farm (total 10,000 late-juveniles). In total, 30,000 juvenile and late-juvenile sea cucumbers were released 


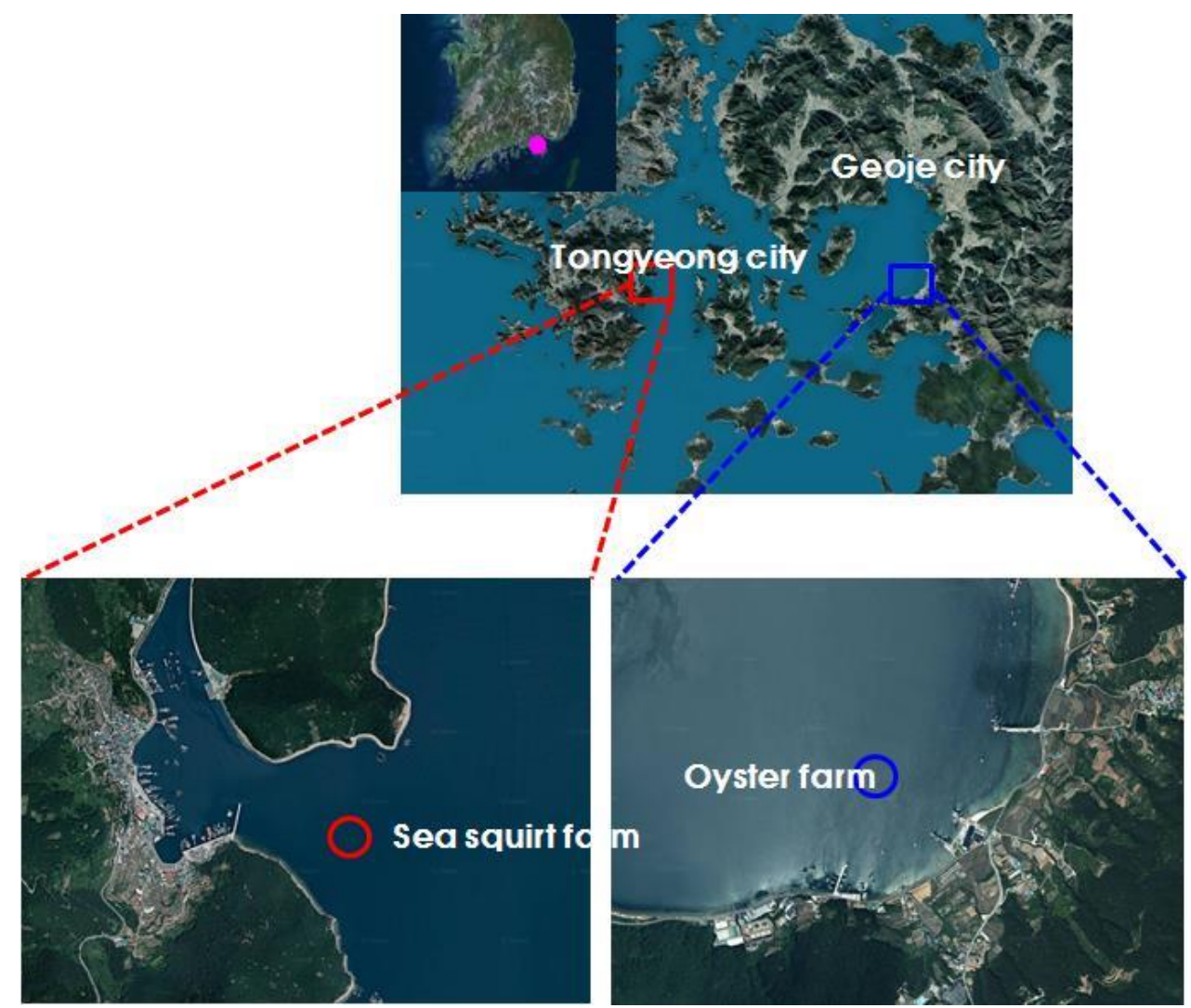

Figure 1. GPS coordinates of the survey sites.

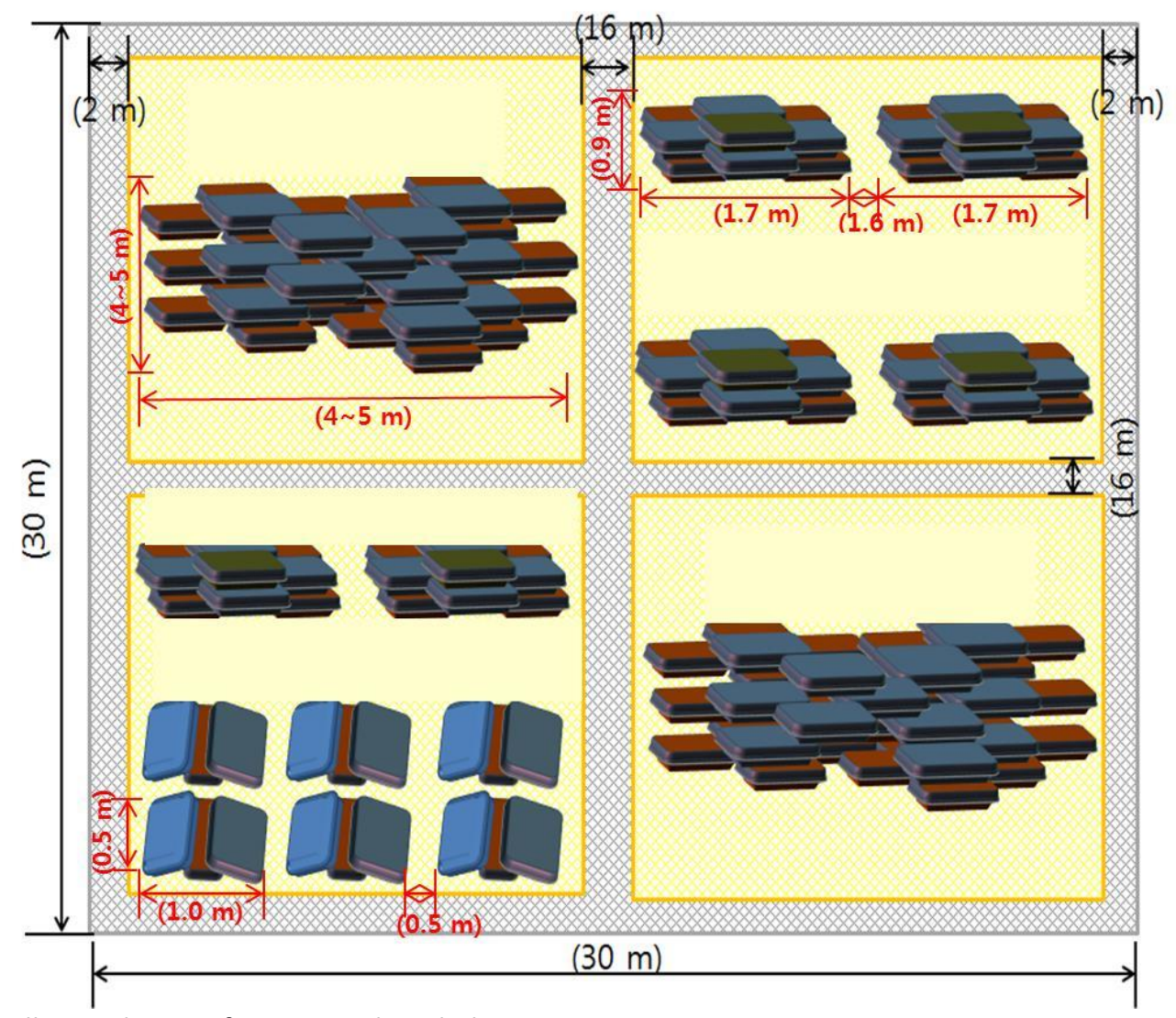

Figure 2. Installation design of sea cucumber shelters. 


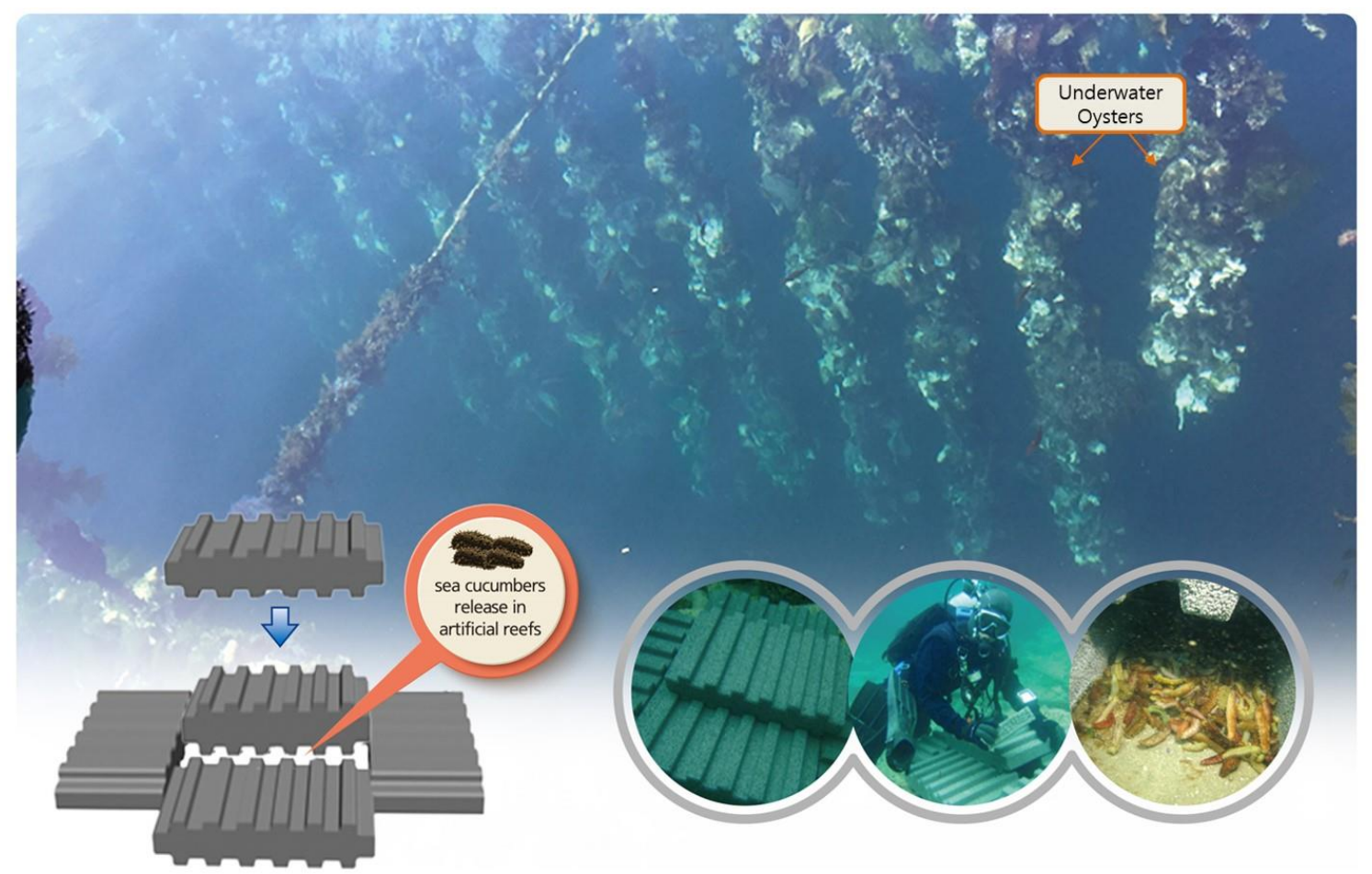

Figure 3. Release of sea cucumbers in the installed shelters.

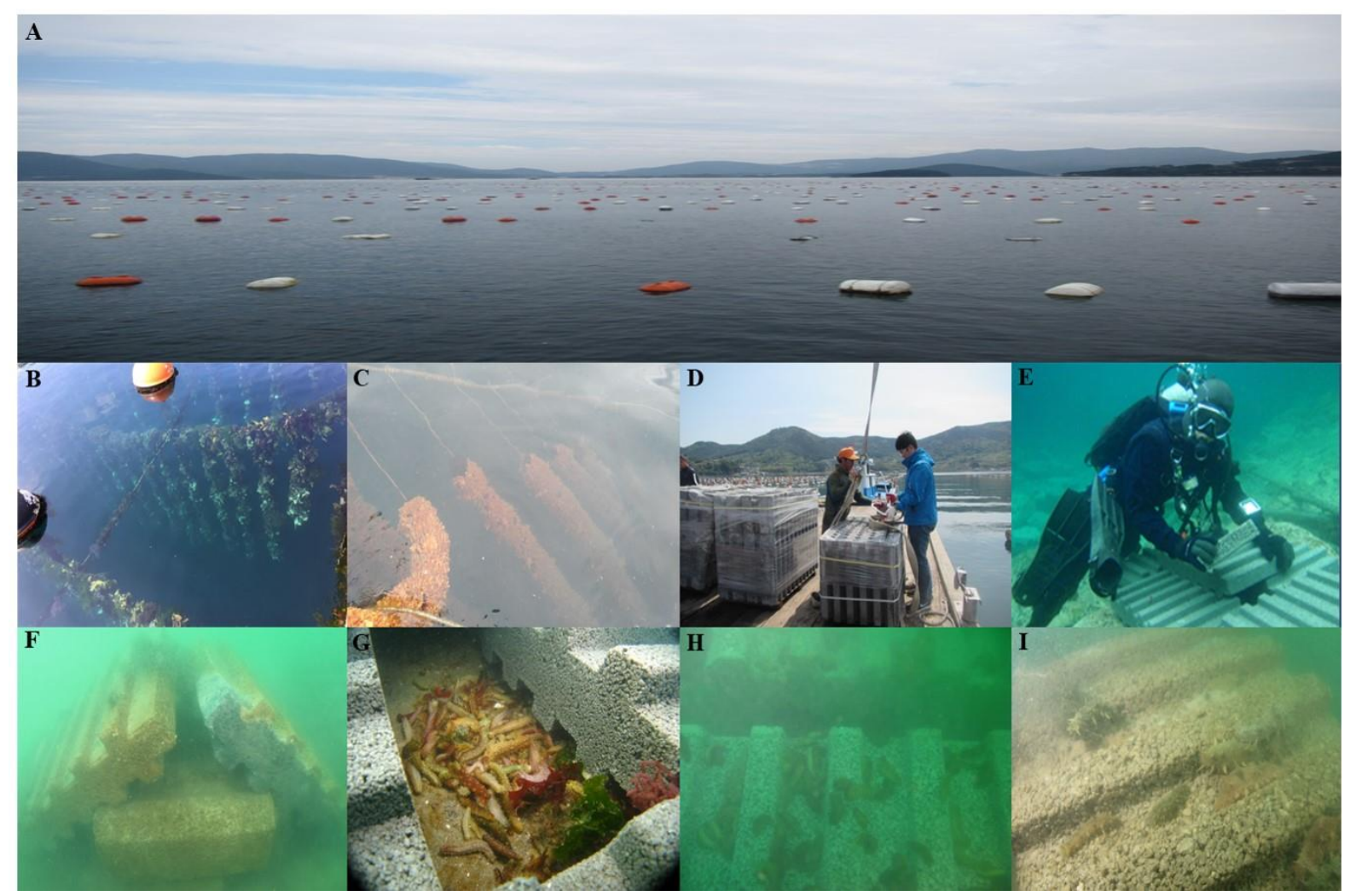

Figure 4. Growth of sea cucumbers in the actual installed shelters A) Aerial view of the oysters and sea cucumber aquaculture form; B) Underwater view of the oyster clusters; C) Underwater view of the sea squirt clusters; D) Preparation of artificial reef facilities; E) Scuba divers prepare to release sea cucumber seeds; F) Sea cucumber released in artificial reefs; G) Sea cucumbers after 5 days of release; H) Sea cucumbers feeding on artificial reefs after 20 days of release; I) Sea cucumber feeding on artificial reefs after 50 days of release. 
$(15,000$ in each hanging culture farm), after acclimatization to seawater temperatures. Both juvenile and late-juvenile sea cucumbers were divided in 1,000 animals and then each group of 1,000 animals was packed into a separate net sack. Divers carried those bags and released sea cucumbers in the shelters.

\section{Growth Survey}

Divers recorded underwater video of sea cucumbers at survey stations using underwater camera (Canon Mark II, Japan) and collected samples from both study areas. Thirty samples each of juvenile and wild late-juvenile sea cucumbers were packed into plastic bags including seawater and ice, transported to the lab within $2 \mathrm{~h}$ and then measured the growth with an electronic scale and Vernier calipers. The growth and inhabitancy in both treatments were recorded using data from previous studies. Length and weight of the samples were measured to the nearest of $0.1 \mathrm{~cm}$ and 0.1 $\mathrm{g}$, respectively.

To identify causes of sea cucumber movement in the treatment area under the oyster farm, data of water temperature and dissolved oxygen (DO) was analyzed and compared with the data obtained from the realtime fishery environment information system of National Institute of Fisheries Science (NIFS), Republic of Korea (data not provided).

\section{Sheltering Rate}

A diving survey was carried out to investigate sea cucumber densities in each type of shelters installed under both experimental conditions. The coverage of diving survey was $900 \mathrm{~m}^{2}(30 \times 30 \mathrm{~m})$ in each of the study areas. Survey was conducted on a monthly basis and densities of habitat were expressed as number of individuals/surveyed area $\left(\mathrm{m}^{2}\right)$. The sea cucumbers found in the surveyed area $\left(30 \mathrm{~m}^{2}\right)$ were collected to calculate inhabitancy densities. Based on the measurements, the length and weight distributions and the resulting densities of inhabitancy were obtained.

\section{Results}

\section{Growth Characteristics of Sea Cucumber in Polyculture}

\section{Growth of Sea Cucumber by Treatment}

Growth pattern of the sea cucumbers released in the hanging culture farms of sea squirt and oyster is shown in Figure 5. At the time of release, the mean weight of the juvenile sea cucumbers in the sea squirt farm was $3.7 \pm 2.9 \mathrm{~g}$. Their growth continued in summer and reached an average weight of $9.1 \pm 3.0 \mathrm{~g}$ in December 2016. The specific growth rate of juveniles was $0.03 \mathrm{~g} /$ day in April, $0.10 \mathrm{~g} /$ day in May, $-0.03 \mathrm{~g} /$ day in August, and $0.43 \mathrm{~g} /$ day in November 2016. Latejuveniles growing under the sea squirt hanging culture farms had a mean weight of $31.5 \pm 5.6 \mathrm{~g}$ at the start of the experiment in April. Their weight declined to $20.8 \pm$ $5.9 \mathrm{~g}$ in September due to estivation, but the weight again increased to a mean weight of $28.8 \pm 13.8 \mathrm{~g}$ in December. The specific growth rate of late-juvenile sea cucumbers was $0.00 \mathrm{~g} /$ day in April, $-0.08 \mathrm{~g} /$ day in May, $-0.35 \mathrm{~g} /$ day in August and $0.38 \mathrm{~g} /$ day in November. At release in April, the average length of juveniles was 33.7 $\pm 11.8 \mathrm{~mm}$, which grew to $61.1 \pm 15.0 \mathrm{~mm}$ in June, 58.2 $\pm 18.6 \mathrm{~mm}$ in August, and $57.0 \pm 11.2 \mathrm{~mm}$ in December. The length of late-juveniles started from $88.8 \pm 14.4 \mathrm{~mm}$ in April, grew to $107.2 \pm 16.2 \mathrm{~mm}$ in June, $88.0 \pm 18.6$ $\mathrm{mm}$ in August, and $79.0 \pm 8.9 \mathrm{~mm}$ in December.

Juveniles released in the oyster farm continued growing in Summer reaching $7.7 \pm 3.1 \mathrm{~g}$ in August, after which the experimental juveniles were not found possibly because they moved due to environmental variations in Summer. The specific growth rate of the juveniles was $0.00 \mathrm{~g} /$ day in April, $0.06 \mathrm{~g} /$ day in May and $-0.02 \mathrm{~g} /$ day in July. Late-juveniles in the oyster hanging culture farm reached an average weight of $33.5 \pm 17.3 \mathrm{~g}$ in June but the weight reduced to $24.6 \pm 5.2 \mathrm{~g}$ in August, and a similar trend was observed for sea cucumbers in the sea squirt farm (Figure 5). In the oyster farm treatment, the average length of juveniles was $33.7 \pm$ $11.8 \mathrm{~mm}$ at the time of release in April, grew to 52.161.1 $\pm 18.5 \mathrm{~mm}$ in June and $55.8 \pm 14.2 \mathrm{~mm}$ in August. The length of late-juveniles was $88.8 \pm 14.4 \mathrm{~mm}$ at the time of release, grew to $100.3 \pm 20.8 \mathrm{~mm}$ in June and $74.5 \pm$ $14.2 \mathrm{~mm}$ in August. Like juveniles, the late-juvenile sea cucumbers also moved to other locations due to the environmental changes in Summer.

The weight of the released juveniles increased until the end of June and then stagnated during July to September. The weight again crept up in October when water temperatures started to decline. The weight of released late-juvenile sea cucumbers also increased until June and during July to August the average weight was reduced to $20 \mathrm{~g}$. The results suggest that a bigger late-juvenile was significantly affected by increasing water temperatures and showed evident signs of estivation with radical loss in feeding activities compared to a juvenile (Figure 6). The relative growth of body length and weight of juveniles in the sea squirt farm was expressed as $y=3.764 X+25.234, R^{2}=0.6578$ and that of late-juveniles was $y=0.9885 X, R^{2}=0.27323$. Similarly, the relative growth of body length and weight of juvenile sea cucumbers in the oyster farm was expressed as $y=2.1084 X+29.974, R^{2}=0.7828$ and that of late-juveniles was $y=1.4895 X+47.168, R^{2}=0.0413$ (Figure 6)

\section{Movement of Sea Cucumbers in the Oyster Farm}

The survey carried out in the early September identified sea cucumbers and their activities in shelters installed under the oyster farm in Geoje-do, Gyeongnam, Rep. of Korea. However, during later survey in the same month sea cucumbers were not 
A

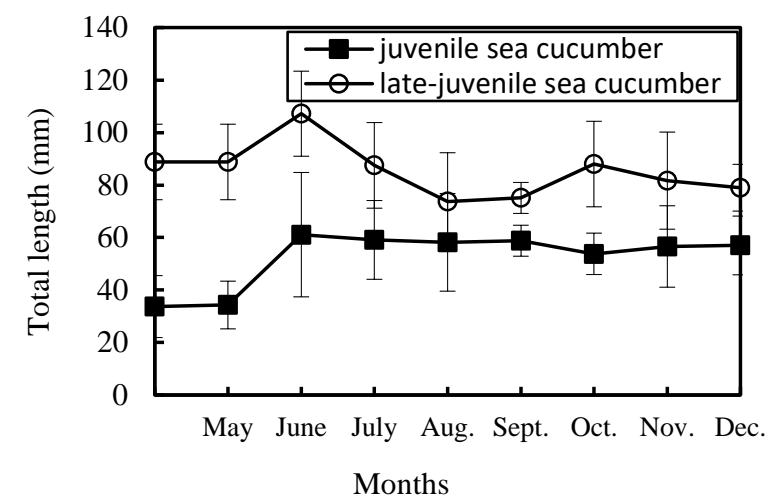

C

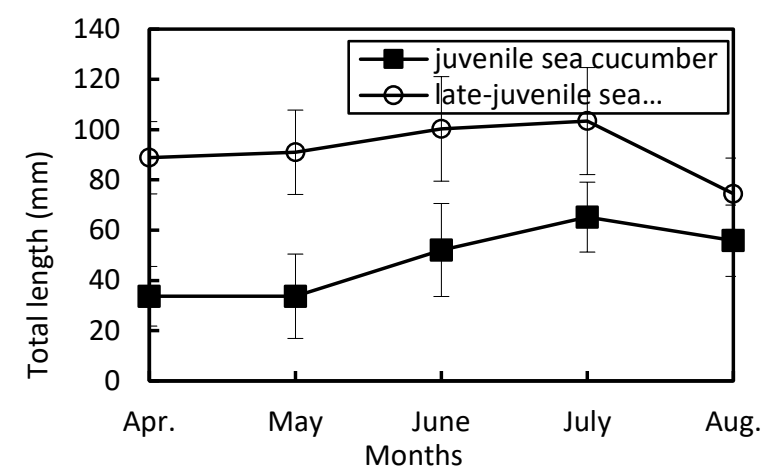

B

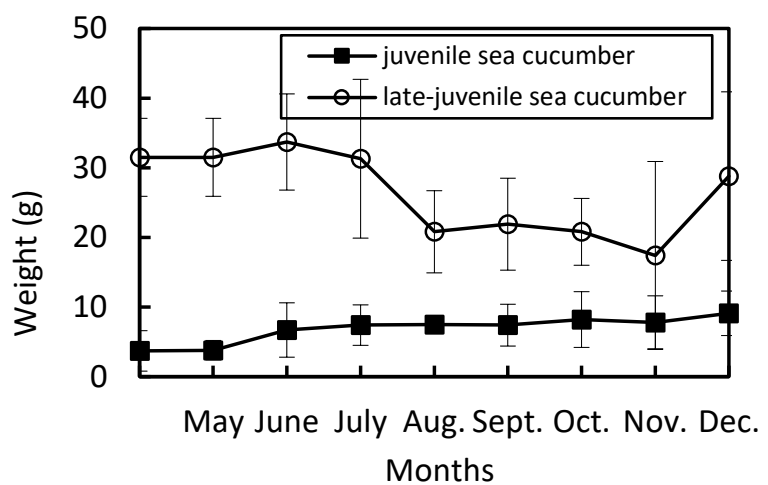

D

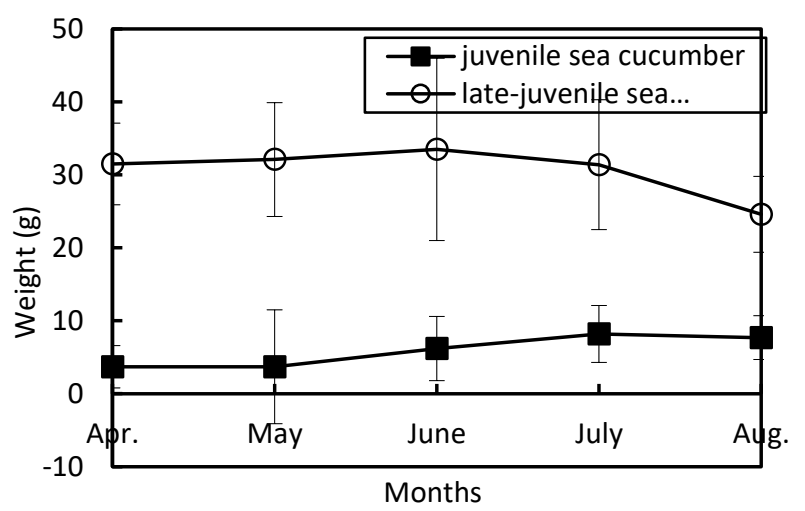

Figure 5. Monthly variations of length and weight of released sea cucumbers A) Monthly variation in total length (mm) of juvenile sea cucumbers in the sea squirt farm; B) Monthly variation in weight (g) of juvenile sea cucumbers in the sea squirt farm; C) Monthly variation in total length $(\mathrm{mm})$ of juvenile sea cucumbers in the oyster farm; D) Monthly variation in weight $(\mathrm{g})$ of juvenile sea cucumbers in the oyster farm.

observed in the shelters. To understand causes of the sea cucumber movement, we analyzed environmental data on the oyster farm (data not provided).

\section{Comparison on the Habitat Environment between Oyster and Sea Squirt Farms}

Parameters of water quality were monthly measured in the study areas (Figure 7). Most of the parameters were found to be within optimal ranges from the time of release until November, however water temperature ranged from $14.3^{\circ} \mathrm{C}$ to $25.0^{\circ} \mathrm{C}$ in the sea squirt farm and from $15.5^{\circ} \mathrm{C}$ to $25.4^{\circ} \mathrm{C}$ in the oyster farm. The DO level of $2.0 \mathrm{mg} / \mathrm{L}$ was observed in the oyster farm in the early September, but in other periods, this parameter was found in an optimal range of 4.6 $9.27 \mathrm{mg} / \mathrm{L}$. Measurements of salinity and $\mathrm{pH}$ ranged from 29.9 to 32.1 and from 8.12 to 9.27 , respectively, which are suitable for sea cucumbers (NIFS, 2009b). DO levels below $3.6 \mathrm{mg} / \mathrm{L}$ cause oxygen deficit and contractions of sea cucumbers (NIFS, 2009b), and it is suggested that DO levels lower than $3.6 \mathrm{mg} / \mathrm{L}$ are not suitable for sea cucumbers habitats.

\section{Causes for the Sea Cucumber Movement in the Oyster Farm}

An analysis on data from the real-time fishery environment information system of NIFS presented DO data measured at the II-un survey station in Geoje-do, Rep. of Korea, from August to October 2016. The data showed a DO level of $8.1 \mathrm{mg} / \mathrm{L}$ on August 3, 2016, but it declined to $5.8 \mathrm{mg} / \mathrm{L}$ on August 19 and then to $1.8 \mathrm{mg} / \mathrm{L}$ on August 22. It further declined to $0.1 \mathrm{mg} / \mathrm{L}$ on September 15 and after which it increased. The air temperature increased at a much faster rate than the water temperature. The surface got warmer with direct sunlight and due to the effect of higher air temperatures. The thermocline contribute to the formation of oxygen deficit water mass in the bottom layer of water, which might have caused the sea cucumbers to move away.

We analyzed variations in water temperature during the study period using data from the real-time fishery environment system of NIFS and data from the Yeongun-ri station of Tongyeong-si. The water temperature in Yeongun-ri, Tongyeong-si was maintained over $24{ }^{\circ} \mathrm{C}$ for 41 days from August 9 to September 18. In Gabae, Geoje-do, the water temperature was maintained over $28{ }^{\circ} \mathrm{C}$ on August 12 and August 13. It is assumed that these elevated levels of water temperature have affected the sea cucumbers habitat.

We compared the measurements of water quality parameters in the sea squirt farm in Tongyeong-si and the oyster farm in Geoje-do and data obtained from nearby survey stations. The results showed that the DO levels measured in the oyster farm on September 10, 
A

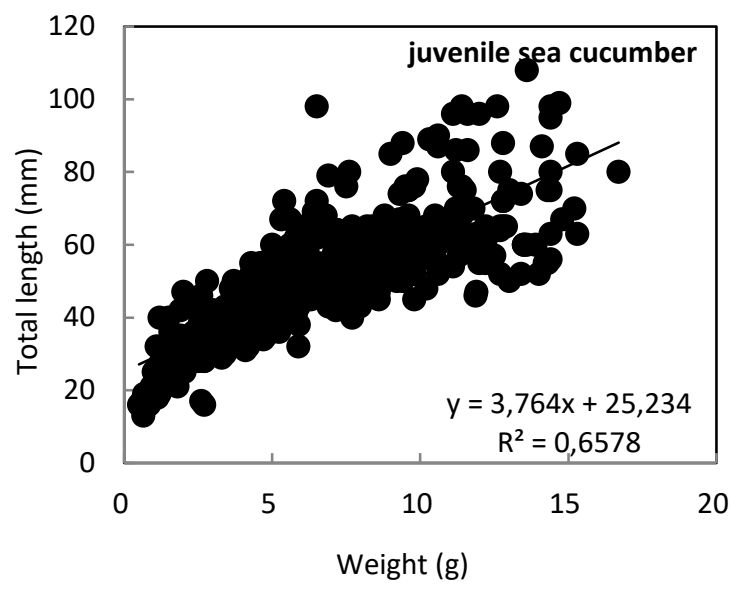

C

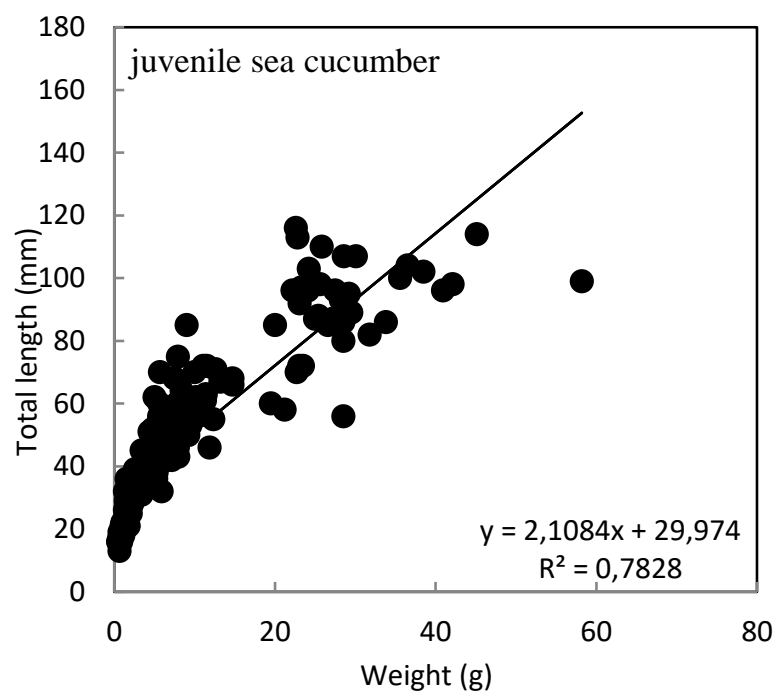

B

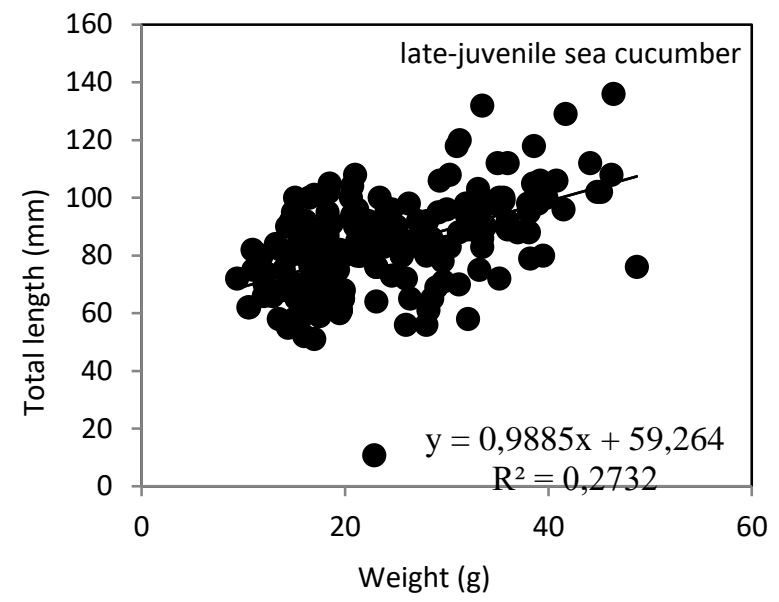

D

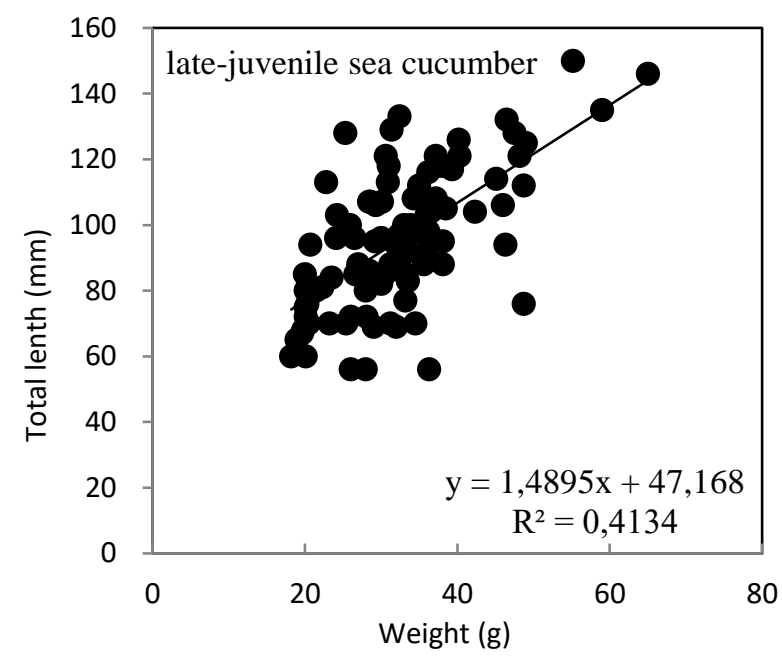

Figure 6. Monthly changes in specific growth rates of total length and weight of sea cucumbers A) Monthly variation in specific growth rate of juvenile sea cucumbers in the sea squirt farm; B) Monthly variation in specific growth rate of adult sea cucumbers in the sea squirt farm; C) Monthly variation in specific growth rate of juvenile sea cucumbers in the oyster farm; B) Monthly variation in specific growth rate of adult sea cucumbers in the oyster farm.

2016 were very low $(2.0 \mathrm{mg} / \mathrm{L} \mathrm{DO})$ which affected the sea cucumbers habitat. The real-time observation data for Tongyeong-si and Goeje-do were provided by NIFS. According to the data analysis, DO measurements at the Ilun station of Geoje-do from August 23 to September 15 were as low as $0.1 \mathrm{mg} / \mathrm{L}$. These low levels of DO may have contributed to the disappearance of sea cucumbers after being last observed in the early September night survey (day 130 of being released).

\section{Sheltering Behavior}

\section{Behavioral Characteristics of Sea Cucumbers}

Sea cucumbers were released under a low velocity of $0.2 \mathrm{~m} / \mathrm{s}$ and to minimize animal loss, the animals were packed in net sacks and carried by divers to underwater shelters, where divers opened the net sack and placed the animals in the shelters. Animals released by divers considerably minimize the animal loss to tide and increase the changes in settlement, but this method is inevitably accompanied by physical stress on animals. It was observed that sea cucumbers kept their bodies shrank or upside-down for approx. 10 min immediately after being released after which they slowly moved using their tube feet on the ventral surface.

\section{Analysis on Usage of Shelters by Sea Cucumbers}

To analyze the usage of shelters, the number of sea cucumbers found on the top, in the middle (the top removed) and on the bottom (shelter being turned over) were observed and the number of sea cucumbers per shelter were calculated (Table 1). It was found that the 
A

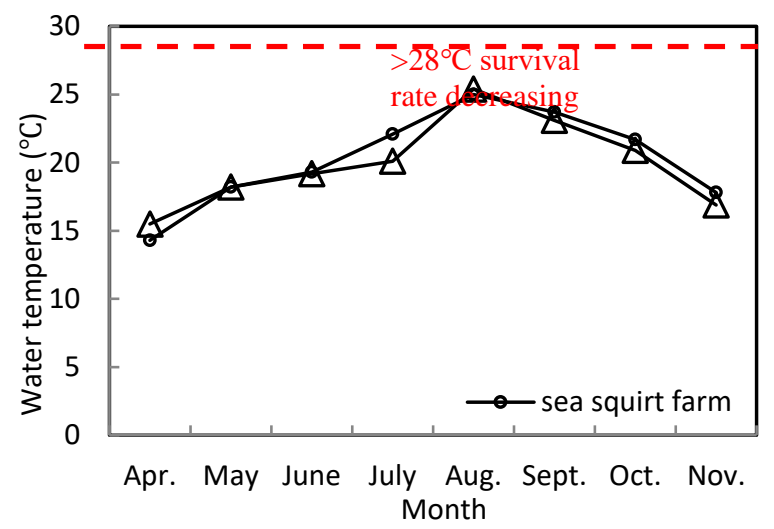

C

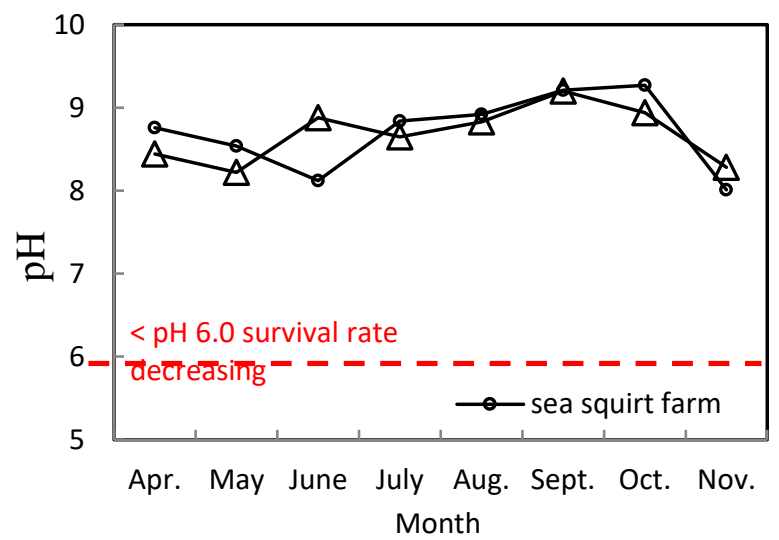

B

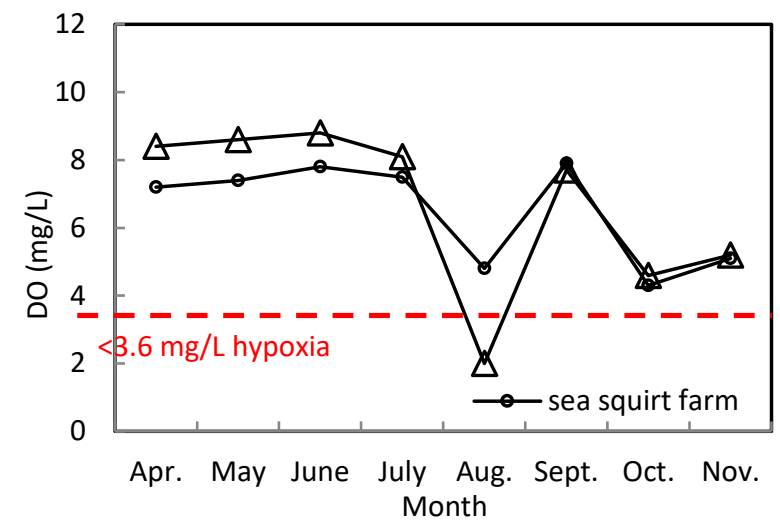

D

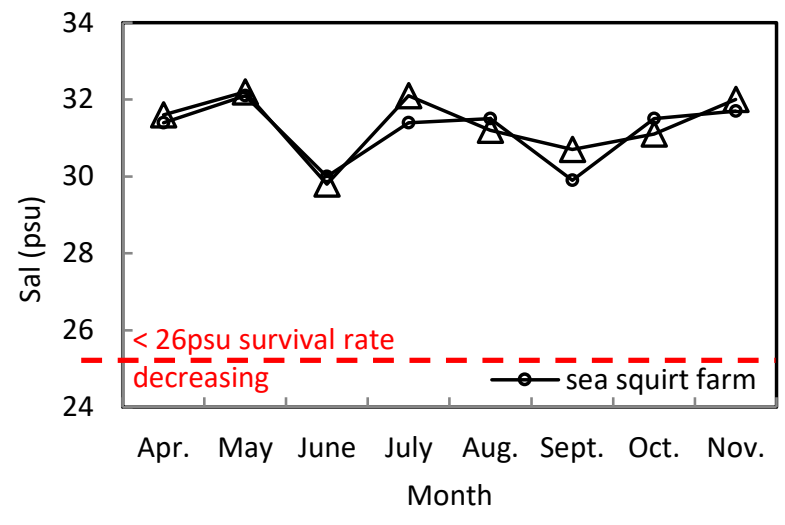

Figure 7. Environmental data for the polyculture farms of sea cucumbers $\mathrm{A})$ Monthly changes in water temperature $\left.\left({ }^{\circ} \mathrm{C}\right) ; \mathrm{B}\right)$ Monthly changes in DO (mg/L) value; C) Monthly changes in $\mathrm{pH}$; D) Monthly changes in salinity (psu).

sea cucumber density was higher on the bottom during daytime and at nighttime sea cucumbers crept up to the top. In the sea squirt farm, the bottom of shelter showed 35.3 animals per shelter in June, 20.0 animals in September, and 18.9 animals in December. In the oyster farm, the sea cucumber density was 44.6 animals per unit on the bottom in June, 27.8 animals on the top in September, after which sea cucumbers were no longer observed.

The habitat preference was also estimated by observing the number of sea cucumbers on the top, in the middle (the top removed) and on the bottom (shelter being turned over). It was observed that sea cucumbers sheltered at the bottom during daytime and made activities on the top in nighttime. In the daytime survey, most of the sea cucumbers sheltered at the bottom and during the nighttime survey; they were observed to be active on the top of shelters. Sea cucumbers in the oyster farms showed the same behavior that they did in the shelters of the sea squirt farm and they were no longer observed after September. The experimental areas were compared with the control area which is mostly muddy. Without shelters, the control showed few sea cucumbers during daytime. The nighttime investigation in August showed sea cucumbers making activities outside of the shelters. It was found that sea cucumbers released on the top of shelter crept inside the shelter and most of the individuals were observed at the bottom of shelter. The nighttime survey in August showed that most of the sea cucumbers were making activities outside of the shelters.

\section{Analysis on Inhabitation Densities of Sea Cucumber in the Polyculture Farms}

According to the analysis on habitation rate in the sea squirt farm, it was $62.3 \%, 45.5 \%, 25.3 \%, 24.5 \%$, $20.8 \%$ and $18.2 \%$, in May, June, July, August, October and November, respectively (Figure 8 ). Whereas, in the oyster farm, the habitation rate was $78.8 \%$ in May, $53.0 \%$ in June, $31.1 \%$ in July and $26.7 \%$ in August. The inhabitation density of the sea cucumbers in shelters was higher in the oyster farm than in the sea squirt farm until August, but after September, sea cucumbers were no longer observed in the oyster farm. The sea squirt farm, showed a stable trend of sea cucumber density in the shelters with $10.40 / \mathrm{m}^{2}$ in May, $4.20 / \mathrm{m}^{2}$ in July, $3.84 / \mathrm{m}^{2}$ in September, and $3.04 / \mathrm{m}^{2}$ in November (Table 2). In the oyster farm, the density was $13.10 / \mathrm{m}^{2}$ in May, 
Table 1. Analysis of habitat densities of sheltered sea cucumbers

\begin{tabular}{|c|c|c|c|c|c|c|c|c|c|}
\hline $\begin{array}{l}\text { Type of } \\
\text { farm }\end{array}$ & $\begin{array}{l}\text { Location of } \\
\text { shelter }\end{array}$ & $\begin{array}{l}\text { April } \\
\text { (at } \\
\text { release) }\end{array}$ & $\begin{array}{l}\text { June } \\
\text { (Day } \\
60)\end{array}$ & $\begin{array}{l}\text { July } \\
\text { (Day } \\
80)\end{array}$ & $\begin{array}{l}\text { Early } \\
\text { September } \\
\text { (Day 130) } \\
\text { (nighttime) }\end{array}$ & $\begin{array}{l}\text { September } \\
\text { (Day 150) }\end{array}$ & $\begin{array}{l}\text { October } \\
\text { (Day 180) }\end{array}$ & $\begin{array}{l}\text { November } \\
\text { (Day 200) }\end{array}$ & $\begin{array}{l}\text { December } \\
\text { (Day 230) }\end{array}$ \\
\hline \multirow{3}{*}{$\begin{array}{l}\text { Sea } \\
\text { squirt } \\
\text { farm }\end{array}$} & $\begin{array}{ll}\text { Top } & \text { of } \\
\text { shelter }\end{array}$ & \multirow{6}{*}{104.17} & 5.5 & 1.2 & 25.6 & 1.0 & - & - & - \\
\hline & $\begin{array}{l}\text { Middle (the } \\
\text { top } \\
\text { removed) }\end{array}$ & & 6.5 & 0.5 & 7.8 & 2.5 & - & - & - \\
\hline & Bottom & & 35.5 & 26.3 & 3.1 & 20.0 & 21.7 & 19.0 & 18.9 \\
\hline \multirow{3}{*}{$\begin{array}{l}\text { Oyster } \\
\text { farm }\end{array}$} & $\begin{array}{l}\text { Top of } \\
\text { shelter }\end{array}$ & & 4.5 & 1.0 & 27.8 & - & - & - & - \\
\hline & $\begin{array}{l}\text { Middle (the } \\
\text { top } \\
\text { removed) }\end{array}$ & & 5.5 & 0.5 & 5.5 & - & - & - & - \\
\hline & Bottom & & 44.6 & 30.5 & 2.0 & - & - & - & - \\
\hline
\end{tabular}

$5.20 / \mathrm{m}^{2}$ in July and $4.45 / \mathrm{m}^{2}$ in September, after which sea cucumbers disappeared.

Among the three types of shelters, type $C$ shelter showed lower densities of habitation (Table 3). It is assumed that the sloped shelters of type $C$ have larger exposure to the environment and the artificial slope has lower functionality as shelter. In July (day 80 of being released), the habitation rate by shelter type in the sea squirt farm were observed as $A(28.0 \%)>B(27.2 \%)>C$ $(19.7 \%)$ and in the oyster farm, it was $A(35.0 \%)>B$ (32.2) > C (22.9\%).

\section{Behavioral Characteristics of Sea Cucumber in Shelter (Nighttime)}

The nighttime survey carried out in the early September (Day 130) revealed that most of the sea cucumbers in the sea squirt and the oyster farms were making activities outside of the shelters. In a later survey in the oyster farm in the same month, no sea cucumber was spotted. The nighttime survey in the early September showed that sea cucumbers got out of the bottom, moved up on the top of shelter and made activities. It was found that most of the animals got off the bottom and were gathered on upper layers of the two or three-tiered shelters. Contrary to the existing knowledge of sea cucumbers aestivation in water, it is known that small-sized sea cucumbers do not estivate. Most of the sea cucumbers in this study were small-sized and did not aestivate.

\section{Discussion}

Every culture of sea cucumber by embankment uses shelter in Korea (MFAFF, 2012). Wild stones are mostly used as shelter in a form of stone pile or long string of stones. These types of shelters allow sea cucumbers to easily take shelter or move freely. Therefore, shelter is critical for culturing sea cucumbers. Previous studies on polyculture of sea cucumbers were carried out by hanging cages of sea cucumbers under water. The long accumulation of organic matter, wastes and dead organisms produced from hanging cultures on seabed contributed to the loss of efficiency and productivity of farms. This study reported the first polyculture of sea cucumber using the seabed under hanging culture farms. From this study, it was analyzed that the habitation rate of sea cucumber was $20 \%$ with 20.8 - 31.0 animals per shelter. The density was calculated to be 3 animals per $\mathrm{m}^{2}\left(\mathrm{~m}^{2} \times 3 \times 900=2,700\right.$ animals), which means about $2,000 \mathrm{~kg}$ of sea cucumbers could be produced from 1 ha $\left(10,000 \mathrm{~m}^{2} \times 200 \mathrm{~g}\right.$; when one individual grows every $\mathrm{m}^{2}$ ). Even though the seabed under the hanging culture farm was muddy and not suitable for sea cucumbers, the results of this study showed that a polyculture of sea cucumber is possible. It is expected that this study will contribute to increase income of aquaculture farmers and it would help to improving the environment of aquaculture farms.

There are numerous studies on the sea cucumber polyculture using abalones, oysters and scallops which were designed to identify the function of sea cucumbers to feed on organic matter and wastes produced by different farmed animals (Paltzat, Pearce, Barnes \& Mckinley, 2008; Nam, Lee, Moon, Kim \& Hwang, 2011; Li, Dong, Gao \& Zhu, 2014). Yu, Zhou, Yang, Ma \& Hu (2014) studied polyculture of fish and sea cucumbers by placing sea cucumber nets under the bottom of a fish cage. Although there is no need for an additional supply of artificial feed for sea cucumbers, monoculture may not be able to supply various and abundant food for sea cucumbers (Li, Dong, Gao \& Zhu, 2014). A polyculture using sea cucumbers is beneficial as it boosts feed efficiency and reduces environmental pollution (Li, 
Table 2. Monthly variations in habitation rate of sea cucumbers

\begin{tabular}{|c|c|c|c|c|c|c|c|c|c|c|c|c|c|c|c|c|c|c|c|c|}
\hline & & \multirow[b]{2}{*}{$\begin{array}{l}\text { No. of } \\
\text { released } \\
\text { animals }\end{array}$} & \multicolumn{2}{|c|}{ April } & \multicolumn{2}{|c|}{ May } & \multicolumn{2}{|c|}{ June } & \multicolumn{2}{|c|}{ July } & \multicolumn{2}{|c|}{$\begin{array}{c}\text { Early } \\
\text { September }\end{array}$} & \multicolumn{2}{|c|}{ September } & \multicolumn{2}{|c|}{ October } & \multicolumn{2}{|c|}{ November } & \multicolumn{2}{|c|}{ December } \\
\hline Survey & station & & $\begin{array}{l}\text { No. of } \\
\text { Ind. }\end{array}$ & Density & $\begin{array}{l}\text { No. of } \\
\text { Ind. }\end{array}$ & Density & $\begin{array}{l}\text { No. } \\
\text { of } \\
\text { Ind. }\end{array}$ & Density & $\begin{array}{l}\text { No. } \\
\text { of } \\
\text { Ind. }\end{array}$ & Density & $\begin{array}{l}\text { No. } \\
\text { of } \\
\text { Ind. }\end{array}$ & Density & $\begin{array}{l}\text { No. } \\
\text { of } \\
\text { Ind. }\end{array}$ & Density & $\begin{array}{l}\text { No. } \\
\text { of } \\
\text { Ind. }\end{array}$ & Density & $\begin{array}{l}\text { No. } \\
\text { of } \\
\text { Ind. }\end{array}$ & Density & No. of Ind. & Density \\
\hline & & 15,000 & & & & & & & & & & & & & & & & & & \\
\hline \multirow[t]{2}{*}{$\begin{array}{l}\text { Sea } \\
\text { squirt }\end{array}$} & Shelter & $\begin{array}{c}\text { Juvenile: } \\
\text { 10,000, } \\
\text { Adult: } \\
5,000\end{array}$ & 15,000 & 16.7 & 9,350 & 10.4 & 6,825 & 7.6 & 3,800 & 4.2 & 3,671 & 4.08 & 3,456 & 3.84 & 3,125 & 3.47 & 2.736 & 3.04 & 2,703 & 3.01 \\
\hline & Control & - & - & - & - & - & - & - & 0.003 & - & - & - & - & - & 0.001 & - & - & - & - & - \\
\hline \multirow[t]{2}{*}{ Oyster } & Shelter & $\begin{array}{c}15,000 \\
\text { Juvenile: } \\
\text { 10,000, } \\
\text { Adult: } \\
5,000\end{array}$ & 15,000 & 16.7 & 11,825 & 13.1 & 7,950 & 8.8 & 4,667 & 5.2 & 4,001 & 4.45 & - & - & - & - & - & - & - & - \\
\hline & Control & - & - & - & 1 & 0.001 & 2 & 0.002 & - & - & - & - & - & - & - & - & - & - & - & - \\
\hline
\end{tabular}

Table 3. Inhabitation rates by shelter type in the polyculture farms

\begin{tabular}{|c|c|c|c|c|c|c|c|c|c|c|c|c|c|c|c|c|c|c|c|c|c|c|c|c|c|c|c|c|}
\hline \multirow[b]{2}{*}{$\underset{\substack{\xi \\
\tilde{w}}}{\xi}$} & \multirow[b]{2}{*}{ 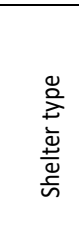 } & \multicolumn{3}{|c|}{ April } & \multicolumn{3}{|c|}{ May } & \multicolumn{3}{|c|}{ June } & \multicolumn{3}{|c|}{ July } & \multicolumn{3}{|c|}{ Early September } & \multicolumn{3}{|c|}{ September } & \multicolumn{3}{|c|}{ October } & \multicolumn{3}{|c|}{ November } & \multicolumn{3}{|c|}{ December } \\
\hline & & 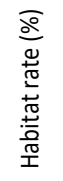 & 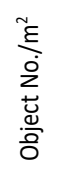 & 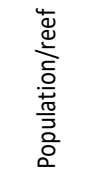 & 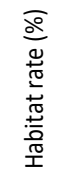 & 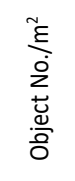 & 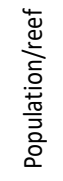 & 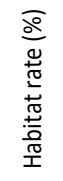 & 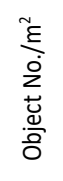 & 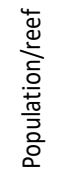 & 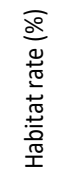 & 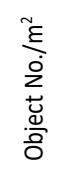 & 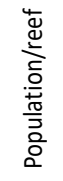 & 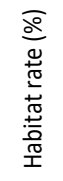 & 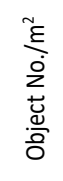 & 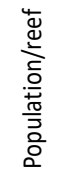 & 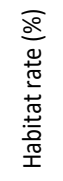 & 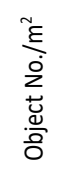 & 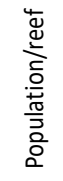 & 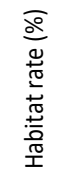 & 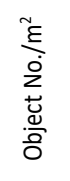 & 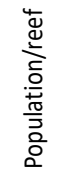 & 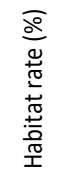 & 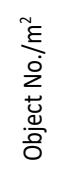 & 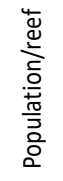 & 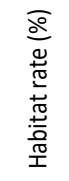 & 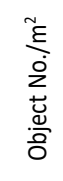 & 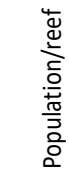 \\
\hline \multirow{4}{*}{$\begin{array}{l}\text { Sea } \\
\text { squirt }\end{array}$} & A1 & 100 & 150 & 104.16 & 61.3 & 92.1 & 64.0 & 46.7 & 70.1 & 48.7 & 28.0 & 42.0 & 29.2 & 28.7 & 43.0 & 29.9 & 26.0 & 39.0 & 27.1 & 24.3 & 36.5 & 25.3 & 21.4 & 32.2 & 22.3 & 31.0 & 21.5 & 20.6 \\
\hline & $\mathrm{A} 2$ & 100 & 150 & 104.16 & 63.3 & 95.7 & 66.5 & 47.5 & 71.2 & 49.4 & 26.4 & 39.6 & 27.5 & 26.4 & 29.6 & 27.5 & 23.9 & 35.8 & 24.9 & 21.6 & 32.4 & 22.5 & 19.0 & 28.5 & 19.8 & 27.7 & 19.3 & 18.5 \\
\hline & B & 100 & 150 & 104.16 & 62.7 & 94.5 & 65.6 & 45.3 & 68.4 & 47.5 & 27.2 & 40.8 & 28.3 & 23.6 & 35.4 & 24.6 & 21.9 & 32.8 & 22.8 & 20.1 & 30.2 & 20.9 & 18.3 & 27.4 & 19.1 & 27.0 & 18.8 & 18.0 \\
\hline & $C$ & 100 & 150 & 104.16 & 62.0 & 93.4 & 64.9 & 42.7 & 64.3 & 44.7 & 19.7 & 29.5 & 20.5 & 19.3 & 28.9 & 20.1 & 20.4 & 30.6 & 21.2 & 17.3 & 25.9 & 18.0 & 14.2 & 21.4 & 14.8 & 20.8 & 14.5 & 13.9 \\
\hline \multirow{4}{*}{ Oyster } & $\mathrm{A} 1$ & 100 & 150 & 104.16 & 80.0 & 120.3 & 83.5 & 55.3 & 83.3 & 57.8 & 35.0 & 52.6 & 36.5 & 29.9 & 44.8 & 31.1 & - & - & - & - & - & - & - & - & - & - & - & \\
\hline & $\mathrm{A} 2$ & 100 & 150 & 104.16 & 76.7 & 115.8 & 80.4 & 52.7 & 79.9 & 55.5 & 34.3 & 51.5 & 35.7 & 26.8 & 40.2 & 27.9 & - & - & - & - & - & - & - & - & - & - & - & \\
\hline & B & 100 & 150 & 104.16 & 84.0 & 126.5 & 87.8 & 54.0 & 81.4 & 56.5 & 32.2 & 48.2 & 33.5 & 26.0 & 39.0 & 27.1 & - & - & - & - & - & - & - & - & - & - & - & \\
\hline & $C$ & 100 & 150 & 104.16 & 74.7 & 112.1 & 77.8 & 50.0 & 75.7 & 52.6 & 22.9 & 34.3 & 18.5 & 24.0 & 35.9 & 25.0 & - & - & - & - & - & - & - & - & - & - & - & \\
\hline
\end{tabular}




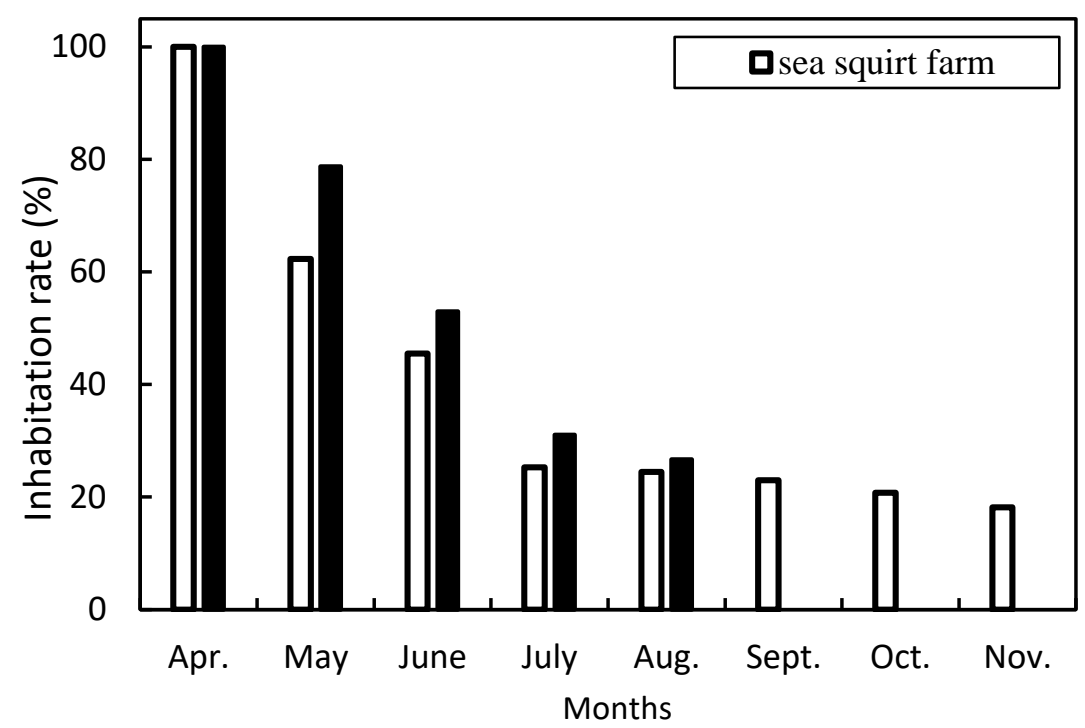

Figure 8. Variations in habitation rate (\%) of sea cucumbers in the poly-culture farms.

Dong, Gao, Wang \& Tian, 2013). However, those benefits can be expected when co-cultured animals have common conditions for habitat environment and do not compete for space (Neori, Shpigel \& Ben-Ezra, 2000). Sea cucumbers start to aestivate at a higher water temperature than $20{ }^{\circ} \mathrm{C}$ (Bao et al. 2010). In Korea, hanging culture farms which have been used for a long time are now getting old and less productive. With the increasing amount of organic matter produced by farmed organisms like oysters, sea squirts and mussels being accumulated on seabed, the need is also growing to study a polyculture method using sea cucumbers to effectively utilize organic matter released from aquaculture farms (Yokoyama, 2015).

A suitable habitat for sea cucumbers is seabed with algae, small rocks or reefs (Lee, Gil, Lee, Kim \& Hur, 2018) or a seabed with a mixture of algae, rocks, and sand (Kang et al. 2012; Yang, Hamel \& Mercier, 2015). A mixture of small rocks and sand with less than $10 \%$ mud could be inhabited by sea cucumbers, but an area with over $27.8 \%$ of mud is not suitable (APFTC, 2012). The hanging culture farms in Gyeongnam province of the Rep. of Korea are mostly muddy on seabed, thus, not suitable to rear sea cucumbers (Kim, Son, Cho \& Jin, 2016). Suitable water depths for sea cucumbers range 5 $\mathrm{m}$ to $10 \mathrm{~m}$ (KFRA, 2013), $5 \mathrm{~m}$ to $20 \mathrm{~m}$ (MAFRA, 2011), and $6 \mathrm{~m}$ to $10 \mathrm{~m}$ (Lee, Lee, Kwak \& Kim, 2013), indicating varying depths depending on location. Hanging culture farms in Gyeongnam province are mostly at depths of 9 $\mathrm{m}$ to $11 \mathrm{~m}$, thus they are suitable for rearing sea cucumbers in terms of water depth. Velocities in this region range from $0.1-0.3 \mathrm{~m} / \mathrm{s}$, which are similar to suitable velocities for sea cucumbers rearing (FAO, 2004). Although Jing et al. (2017) reported that sea cucumbers with lower oxygen consumption than other organisms are resistant to oxygen deficiency; suitable oxygen levels of over $5.0 \mathrm{mg} / \mathrm{L}$ are recommended (Kim et al. 2017b).

Paltzat, Pearce, Barnes \& Mckinley (2008) demonstrated that the North American sea cucumber (Parastichopus californicus) grows slowly reaching to 218 - $489 \mathrm{~g}$ in 4 - 5 years. Reared on smaller trays, however, they achieved a faster growth than in the wild growing to $43.6 \mathrm{~g}$ in 10 months and $63.5 \mathrm{~g}$ in 12 months. According to MFAFF (2012) juveniles released in May at $2.4 \mathrm{~g}$ grew to $20.6 \mathrm{~g}$ in November in an experiment carried out in a cage farm with a survival rate of $53.4 \%$ and a specific growth rate of $0.0408 \mathrm{~g} /$ day. In an experiment using abalone cage the group of big juvenile sea cucumbers released at a weight of $7.2 \mathrm{~g}$ grew up to $95.5 \mathrm{~g}$ in 2 years with a specific growth rate of 0.1226 $\mathrm{g} /$ day and the group of smaller juveniles grew to $57.7 \mathrm{~g}$ with a specific growth rate of $0.0701 \mathrm{~g} /$ day and a survival rate of $58.1 \%$ (NIFS, 2016). In an embankment pond using burlap bags as shelter, juveniles released at $1.15 \mathrm{~g}$ grew to $52.0 \mathrm{~g}$ in a 7 month period with a survival rate of $74.1 \%$, after which all animals died due to low salinity caused by the heavy rains (NIFS, 2016). In another experiment in an embankment pond using stone piles as shelter, juveniles released at $9.9 \mathrm{~g}$ grew to an average of $130 \mathrm{~g}$ after 1 year with a survival rate of $19.7 \%$ and a specific growth rate of $0.3336 \mathrm{~g} /$ day (MFAFF, 2012).

Ren, Dong, Wang, Gao \& Jiang (2014) demonstrated that in a polyculture of fish and sea cucumbers, the production volume of sea cucumber was much higher than that of fish. The juveniles in the present experimental sea squirt farm continued growing in Summer and reached an average weight of $9.1 \pm 3.0 \mathrm{~g}$ in December. The specific growth rate in the sea squirt farm was $0.03 \mathrm{~g} /$ day in April 2016, $0.10 \mathrm{~g} /$ day in May, $0.03 \mathrm{~g} /$ day in August, and $0.43 \mathrm{~g} /$ day in November. Latejuveniles showed an average weight of $31.5 \pm 5.6 \mathrm{~g}$ in 
April, but weights declined to $20.8 \pm 5.9 \mathrm{~g}$ in early September due to estivation and then grew again to $28.8 \pm 13.8 \mathrm{~g}$ in December. The specific growth rate was $0.00 \mathrm{~mm} /$ day in April, $-0.08 \mathrm{~mm} /$ day in May, -0.35 $\mathrm{mm} /$ day in August, and $0.38 \mathrm{~mm} /$ day in November. In the experimental oyster farm, the weight of the released juveniles continued increasing in Summer reaching an average of $7.7 \pm 3.1 \mathrm{~g}$ by August, after which sea cucumbers were no longer observed possibly because they moved away due to the environmental effects in Summer. The specific growth rate of juvenile sea cucumbers was $0.00 \mathrm{~g} /$ day in April, $0.06 \mathrm{~g} /$ day in May, and $-0.02 \mathrm{~g} /$ day in July. The released late-juveniles in the oyster farm grew to an average of $24.6 \pm 5.2 \mathrm{~g}$ in July, but their weight declined to an average of $24.6 \pm 5.2 \mathrm{~g}$ in August, undergoing the estivation. The specific growth rate of juvenile sea cucumbers was $0.02 \mathrm{~g} /$ day in April, $0.05 \mathrm{~g} /$ day in May, and $-0.23 \mathrm{~g} /$ day in July. In a study by Yokoyama (2015) juvenile sea cucumbers grew from $0.12 \mathrm{~g}$ to $7.4 \mathrm{~g}$ in 168 days. According to Park, Han, Hwang, Kwon \& Kim (2017) the average distance and movement rate of big-sized sea cucumbers (100.65 \pm $3.07 \mathrm{~g}$ ) in an indoor environment was $1.43 \mathrm{~m}$ and 4.34 $10^{-3} \mathrm{~m} / \mathrm{s}$, respectively. Middle-sized sea cucumbers $(55.95 \pm 4.13 \mathrm{~g})$ showed $0.77 \mathrm{~m}, 2.3610^{-3} \mathrm{~m} / \mathrm{s}$, and the small-sized sea cucumbers (13.05 $\pm 5.17 \mathrm{~g})$ showed 0.06 $\mathrm{m}$ of moved distance and $1.7610^{-3} \mathrm{~m} / \mathrm{s}$ of movement rate.

In the study of Oh et al. (2013) the maximum distance of movement was $0.75 \mathrm{~m}$ at a water temperature of $10^{\circ} \mathrm{C}, 0.1 \mathrm{~m}$ at $13^{\circ} \mathrm{C}$, and $0.2 \mathrm{~m}$ at $19{ }^{\circ} \mathrm{C}$. Nam, Lee, Moon, Kim \& Hwang (2011) carried out an experimental polyculture of abalone and sea cucumber and found that sea cucumbers grew at an average monthly rate of $5.4 \mathrm{~g}$ in the east coast type of farm and at an average monthly rate of $4.8 \mathrm{~g}$ in the south coast type. The present study showed a continual growth without estivation, which was assumed to be because the animals were reared at temperatures below $20^{\circ} \mathrm{C}$ at a depth of $15 \mathrm{~m}$. Lee, Gil, Lee, Kim \& Hur (2018) presented that sea cucumbers with an average weight of $2.3 \mathrm{~g}$ grew to $12.5 \mathrm{~g}$ in an experimental area of reefs after 1 year with a specific growth rate of $0.03 \mathrm{~g} / \mathrm{day}$. It is known that at a higher water temperature than 25 으, sea cucumbers move to a deeper depth to estivate. The same phenomenon has also been observed in mollusk species and some other fish species (Tingting, Yunwei \& Shuanglin, 2008).

According to Lee, Gil, Lee, Kim \& Hur (2018) the reef treatment showed the sea cucumber density of $23.7 / \mathrm{m}^{2}$, whereas the stone, algae, and sand treatment showed a density of $2.0 / \mathrm{m}^{2}, 1.9 / \mathrm{m}^{2}$, and $0.8 / \mathrm{m}^{2}$, respectively. During the estivation period, the observed density was $0.9 \mathrm{~m}^{2}$ in the stone treatment, $1.0 \mathrm{~m}^{2}$ in the algae treatment, and $0.4 \mathrm{~m}^{2}$ in the sand treatment and in the period of declining water temperature in October, the sea cucumber density was $19.9 / \mathrm{m}^{2}$ in the reef treatment, $2.0 \mathrm{~m}^{2}$ in the stone treatment, $2.7 \mathrm{~m}^{2}$ in the algae treatment and $1.8 \mathrm{~m}^{2}$ in the sand treatment (Lee,
Gil, Lee, Kim \& Hur, 2018). It was reported that the sea cucumber production of an embankment pond in China produced 2 - 3 MT (MFAFF, 2012), which is similar to the results of the present study, while results of previous studies in Rep. of Korea differed in terms of growth and survival rates. Thus, there is a need to carry out further in-depth studies in future.

\section{Acknowledgements}

This study was supported by a grant from the National Institute of Fisheries Science (NIFS), Republic of Korea under the project; Authors are thankful for their support.

\section{References}

Ahlgren, M.O. (1998). Consumption and assimilation of salmon net pen fouling debris by the red sea cucumber Parastichopus californicus implications for polyculture. Journal of the World Aquaculture Society, 29(2), 133$139 . \quad$ https://dx.doi.org/10.1111/j.17497345.1998.tb00972.x

APFTC, (2012). The ecology and resource management of sea cucumber Stichopus japonicus, Aoki Prefecture Fisheries Technology Center. Retrieved from http://www.aomoriitc.or.jp/public/zoshoku/dayori/114g/114_p8-10.pdf

Bao, J., Dong, S.J., Tian, X.L., Gao, Q.F., Wang, F., Dong, Y.W., \& Jiang, H.B. (2010). Metabolic rates and biochemical compositions of Apostichopus japonicus tissue during periods of inactivity. Chinese Journal of Oceanology and Limnology, 28(2), 218-223. https://dx.doi.org/10.1007/s00343-010-9016-3

Bordbar, S., Anwar, F., \& Saari, N. (2011). High-value components and bioactives from sea cucumbers for functional foods-A review. Marine Drugs, 9(10), 1761 1805. https://dx.doi.org/10.3390/md9101761

Chang, Y. Q., Yu, C. Q., \& Song, X. (2004). Pond culture of sea cucumber, Apostichopus japonicus, in Dalian. In: Advances in sea cucumber aquaculture and management, Lovatelli, A., Conand, C., Purcell, S., Uthicke, S., Hamel, J. F., \& Mercier, A. (eds.). Rome: FAO, pp. 269-272.

FAO, (2004). Advances in the sea cucumber aquaculture and management, Food and Agriculture Organization of the United Nations, Rome., 256 pp.

Hatcher, A., Grant, J., \& Schofield, B. (1994). Effects of suspended mussel culture (Mytilus spp) on sedimentation, benthic respiration and sediment nutrient dynamics in a coastal bay. Marine Ecology Progress Series, 115, 219-235.

Jaramillo, E., Bertrain, C., \& Bravo, A. (1992). Mussel biodeposition in an estuary in southern Chile. Marine Ecology Progress Series, 82, 85-94.

Jing, S., Zhou, F., Mo, X., Huang, J., Yang, Q., \& Yang, L. (2017). Polyculture of sea cucumber Holothuria scabra with pacific white shrimp Litopenaeus vannamei. The Israeli Journal of Aquaculture, 69.2017.1429, 1-8. http://hdl.handle.net/10524/57049

Kang, S.J., Kang, S.W., Kang, J.H., Jung, W.C., Choi, B.D., \& Han, J.C. (2012). Sea cucumber aquaculture technology. Aquainfo, Seoul, Republic of Korea., 426 pp. 
KFRA, (2013). The development project of sea cucumber island in Yangyang-gun. Korea Fisheries Resources Agency, FIRA-PR-2013-027., 173 pp.

Kim, T.I., Son, M.H., Cho, J.K., \& Jin, Y.G. (2016). Observation of external injury and morphological movement for analysis of recovery possibility after storage of the juvenile sea cucumber, Apostichopus japonicus. JFMSE, 28(4), 1006-1013. http://dx.doi.org/10.13000/JFMSE.2016.28.4.1006

Kim, Y.D., Park, M., Nah, G., Kim, J., Jhang, G., Shin, Y.K., ... Choi, J.-S. (2017a). Development of microsatellite markers and genetic diversity analysis of sea cucumber from Korean peninsula. SYLWAN, 161(11), 118-136.

Kim, Y.D., Park, M.S., Park, M.A., Shin, Y.K., Her, Y.B., Park, Y.S., ... Baek, J.E. (2017b). A Study on the polyculture of Sea squirt halocynthia roretzi and Sea cucumber Apostichopus japonicus under a hanging culture system. National Institute of Fisheries Sciences, Republic of Korea., 107 pp.

Lee, C.H., Lee, D.H., Kwak, S.N., \& Kim, H.W. (2013). A preliminary study in habitat characteristics and settlement of released sea cucumber, Apostichopus japonicus in the coastal waters of Korean peninsula. Journal of Fisheries Resources Management, 3, 113-127.

Lee, J.W., Gil, H.W., Lee, D.H., Kim, J.K., \& Hur, J.W. (2018). Variation of size and density of sea cucumber (Apostichopus japonicus) released to the habitat conditions. Ocean and Polar Research, 40, 69-75.

Li, J., Dong, S., Gao, Q., \& Zhu, C. (2014). Nitrogen and Phosphorus budget of a polyculture system of a sea cucumber (Apostichopus japonicus), jellyfish (Rhopilema esculenta) and shrimp (Fenneropenaeus chinensis). Journal of Ocean University of China, 13(3), 503-508. https://dx. doi.org/10.1007/s11802-014-2181-9

Li, J.W., Dong, S.G., Gao, Q.F., Wang, F., \& Tian, X.L. (2013). Total organic carbon budget of integrated aquaculture system of sea cucumber Apostichopus japonicus jelly fish Rhopilema esculenta and shrimp Fenneropenaeus chinensis. Aquaculture Research, 45(11), 1825-1831. https://dx.doi.org/10.1111/are.12131

MacTavish, T., Stenton-Dozey, J., Vopel, K., \& Savage, C. (2012). Deposit-feeding sea cucumbers enhance mineralization and nutrient cycling in organicallyenriched coastal sediments. PLOS ONE, 7, e50031. https://doi.org/10.1371/journal.pone.0050031

MAFRA, (2011). The guidebook for aquaculture of sea cucumber Stichopus japonicus, Ministry of Agriculture, Food and Rural Affairs, Sejong-si, Republic of Korea., 134 pp.

MFAFF, (2012). SEA cucumber pilot research project. Ministry of Food Agriculture Forestry and Fisheries, Republic of Korea., $450 \mathrm{pp}$.

MOF, (2017). Fisheries statistical information service. Retrieved from http://www.fips.go.kr/p/S02/\#none

Moriarty, D.J.W. (1982). Feeding of Holothuria atra and Stichopus chloronotus on bacteria organic carbon and organic nitrogen in sediments of the great barrier reefs. Australian Journal of Marine and Freshwater Research, 33(2), 255-263. https://dx.doi.org/10.1071/MF9820255

$\mathrm{Mu}$, J., \& Song, J. (2005). Technology of the raft caged Apostichopus japonicus aquaculture in epicontinental seas. Science of Fish Farming, 3, 39 (in Chinese).

Nam, M.M., Lee, C.M., Moon, T.S., Kim, S.K., \& Hwang, J.W. (2011). Analysis of production of a polyculture container for suspended rearing of abalones and sea cucumbers.
Korean Journal of Malacology, 27(4), 232-330. https://dx.doi.org/10.9710/kjm.2011.27.4.323

Neori, A., Shpigel, M., \& Ben-Ezra, D. (2000). A sustainable integrated system for culture of fish, seaweed and abalone. Aquaculture, 186(3-4), 279-291. https://dx.doi.org/10.1016/S0044-8486(99)00378-6

NIFS, (2009a). The studies on stability of cultured sea squirt aquaculture fisheries, National Institute of Fisheries Sciences, Republic of Korea., $311 \mathrm{pp}$.

NIFS, (2009b). Hypoxia in the coast of Korea, National Institute of Fisheries Science, Republic of Korea., $173 \mathrm{pp}$.

NIFS, (2016). T/F report on Sea cucumber industry development, National Institute of Fisheries Science, Republic of Korea., 48 pp.

Oh, M.H., Kwon, I.Y., Kim, B.R., Shin, J.H., Yu, H.H., ... Kim, T.H. (2013). Movement patterns of sea cucumber (Apostichopus japonicus) by changing water temperature in the indoor water tank. Bulletin of the Institute of Fishing Technology Chonnam National University, 6(1), 10-17.

Paltzat, D.L., Pearce, C.M., Barnes, P.A., \& Mckinley, R.S. (2008). Growth and production of California sea cucumbers (Parastichopus californicus) co-cultured with suspended pacific oysters (Crassostrea gigas). Aquaculture, 275(1-4), 124-137. https://dx.doi.org/10.1016/j.aquaculture.2007.12.014

Park, S., Han, S.H., Hwang, H.W., Kwon, I.Y., \& Kim, T.H. (2017). Behavioral characteristics of sea cucumber (Apostichopus japonicus) on shelter selectivity by body size in indoor water tank. Bulletin of the Institute of Fishing Technology Chonnam National University, 10(1), 13-19. https://dx.doi.org/10.15399/jfti.2017.02.10.1.13

Purcell, S. (2004). Rapid growth and bioturbation activity of the sea cucumber Holothuria scabra in earthen ponds. Proceedings of Australasian Aquaculture, 1, 244.

Purcell, S.W., Conand, C., Uthicke, S., \& Byrne, M. (2016). Ecological roles of exploited sea cucumbers. Oceanography and Marine Biology: An Annual Review, 54, 367-386. https://doi.org/10.1201/9781315368597-8

Purcell, S.W., Samyn, Y., \& Conand, C. (2012). Commercially important sea cucumbers of the world. FAO Species Catalogue for Fishery Purposes No. 6. Rome: FAO.

Ren, Y., Dong, S., Wang, X., Gao, Q., \& Jiang, S. (2014). Beneficial co-culture of jellyfish Rhopilema esculenta and sea cucumber Apostichopus japonicus: implications for pelagic-benthic coupling. Aquaculture Research, 45(2), 177-187. https://dx.doi.org/10.1111/j.13652109.2012.03225.x

Schneider, K., Silverman, J., Kravitz, B., Rivlin, T., SchneiderMor, A., Barbosa, S., Byrne, M., \& Caldeira, K. (2013). Inorganic carbon turnover caused by digestion of carbonate sands and metabolic activity of holothurians. Estuarine, Coastal and Shelf Science, 133, 217-223. https://doi.org/10.1016/j.ecss.2013.08.029

Schneider, K., Silverman, J., Woolsey, E., Eriksson, H., Byrne, M., \& Caldeira, K. (2011). Potential influence of sea cucumbers on coral reef $\mathrm{CaCO}_{3}$ budget: a case study at one Tree Reef. Journal of Geophysical Research G: Biogeosciences, 116, G04032. https://doi.org/10.1029/2011JG001755

Solan, M., Cardinale, B.J., Downing, A.L., Engelhardt, K.A.M. Ruesink, J.L., \& Srivastava, D.S. (2004). Extinction and ecosystem function in the marine benthos. Science, 306, $1177-1180$.

https://dx.doi.org/10.1126/science.1103960 
Tingting, J., Yunwei, D., \& Shuanglin, D. (2008). Growth and physiological responses in the sea cucumber, Apostichopus japonicus, Aestivation and temperature. Aquaculture, 283(1-4), 180-187. https://dx.doi.org/10.1016/j.aquaculture.2008.07.006

Xing, K., Liu, S., Yang, H., Zhang, M., \& Zhou, Y. (2012). Southward transplanted cage-culture of sea cucumbers Apostichopus japonicus, in China's shengsi islands. SPC Beche-de-mer Information Bulletin, 32, 33-38.

Yang, H.S., Hamel, J.F., \& Mercier, H.A. (2015). The sea cucumber Apostichopus japonicus history, biology and aquaculture. Academic Press, Elsevier, USA., 478 pp.

Yingst, J.Y. (1982). Factors influencing rates of sediment ingestion by Parastichopus parvimensis, an epibenthic deposit-feeding holothurian. Estuarine, Coastal and Shelf Science, 14(2), 119-134. https://dx.doi.org/10.1016/S0302-3524(82)80040-6

Yokoyama, H. (2015). Suspended culture of the sea cucumber Apostichopus japonicus below a pacific oyster raftpotential for integrated multi-trophic aquaculture. Aquaculture Research, 46(4), 825-832. https://dx.doi.org/10.1111/are.12234
Yu, Z. H., Hu, C. Q., Qi, Z. H., Jiang, H. Y., Ren, C. H., \& Luo, P. (2012). Co-culture of sea cucumber Holothuria leucospilota with the Pacific white shrimp Litopenaeus vannamei. Journal of Fisheries China, 36, 1081-1087. (in Chinese with English abstract)

Yu, Z., Zhou, Y., Yang, H., Ma, H., \& Hu, C. (2014). Survival, growth, food availability and assimilation efficiency of the sea cucumber Apostichopus japonicus bottomcultured under a fish farm in the southern China. Aquaculture, 426-427, 238-248. https://dx.doi.org/10.1016/j.aquaculture.2014.02.013

Yuan, X., Zhou, Y., \& Mao, Y. (2015). Chapter 17 - Apostichopus japonicus: A key species in integrated polyculture systems. In: the sea cucumber Apostichopus japonicus: History, biology and aquaculture, Yang, H., Hamel, J.-F., \& Mercier, A. (eds). Developments in Aquaculture and Fisheries Science, 39, 323-332. https://doi.org/10.1016/B978-0-12-799953-1.00017-9

Yuan, X.T., Yang, H.S., Zhou, Y., Mao, Y.Z., Xu, Q., \& Wang, L.L. (2008). Bioremediation potential of Apostichopus japonicus in coastal bivalve suspension aquaculture system. Ying Yong Sheng Tai Xue BaoJournal of Applied Ecology, 19, 866-872. 